\title{
A Novel Wideband Partially Reflective Surface for Antenna Gain Enhancement
}

\author{
Abdelhalim Chaabane*
Laboratoire des Télécommunications-LT, Département d'Electronique et Télécommunications, Faculté des Sciences et de la Technologie, Université 8 Mai 1945 Guelma, BP 401, Guelma 24000, Algeria

(Received 10 August 2020; revised manuscript received 16 December 2020; published online 25 December 2020)

\begin{abstract}
A novel wideband partially reflective surface (PRS) for printed antennas gain enhancement is proposed in this paper. The proposed PRS is constructed by two layers separated by an air-gap. It is composed by an inductive patch with a star flower-shaped aperture etched on the bottom faces of its two layers and a capacitive star flower-shaped patch that is placed on the top face of its upper layer. The presented PRS with a broadband operation extending from $7.76 \mathrm{GHz}$ to $11.16 \mathrm{GHz}$ is proposed to improve the gain of printed antennas operating around this band. The usefulness of the proposed PRS is examined by placing an array of $8 \times 9$ over a single-layer printed feeding antenna (FA). The gain of the considered FA is considerably enhanced after the implementation of the PRS. Hence, the usefulness of the designed PRS is demonstrated for enhancing the gain of printed antennas operating in X-band.
\end{abstract}

Keywords: Partially reflective surface (PRS), Feeding antenna (FA), Wideband, Gain enhancement.

DOI: 10.21272/jnep.12(6).06010

\section{INTRODUCTION}

Nowadays, due to the rapid expansion of wireless communication systems domain, the request of highgain and wideband directive antennas has acquired great focus $[1,2]$. To not refer to a complex feed network, the helpful and the simplest technique to improve the radiation performance of printed antennas is to implement a Fabry-Perot cavity; by placing electromagnetic-band-gap structures as a partially reflective surface (PRS) at a proper distance along their direction of propagation. Here, the role of the PRS is to create a partial blocking for the radiated waves emitted by the feeding antenna (FA). Accordingly, the radiated waves incur several reflections before their escape throughout the PRS as extremely directive emission [3-12]. FabryPerot cavity that was firstly introduced in 1956 by Von Trentini is well known for its aptitude to enhance the gain of printed antennas by the implementation of mightily reflective surfaces at a delicate altitude in order to create constructive wave interference between the direct rays radiated by the FA and the rays reflected by the PRS [13-19]. The reflection coefficient behavior of the PRS has significant influence on the radiation performance of the resulting electromagnetic-band-gap antenna [20]. Hence, there is a consistent need to design a novel PRS which has good behavior to enhance the performance of printed antennas.

In this paper, a broadband double-layer PRS having an enhanced inclining reflection phase in X-band is presented. An array formed by $8 \times 9$ of the designed PRS is placed over a single-layer printed FA to demonstrate its effectiveness for improving the gain of printed antennas. The entire designs were performed employing the commercial software Computer Simulation Technology (CST) Microwave Studio ${ }^{\mathrm{TM}}$.

\footnotetext{
* abdelhalim.chaabane@univ-guelma.dz

* chaabaneabdelhalim1979@gmail.com

* chaabaneabdelhalim@yahoo.fr
}

PACS numbers: 07.60 Ly, 42.25.Bs, 42.70.Qs, 42.82.Et, 84.40.Ba, 95.85.Bh 


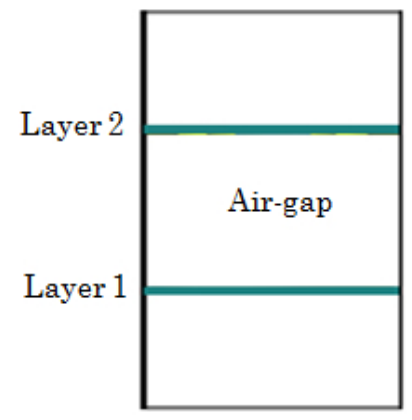

Fig. 1 - Perspective view of the proposed PRS unit-cell

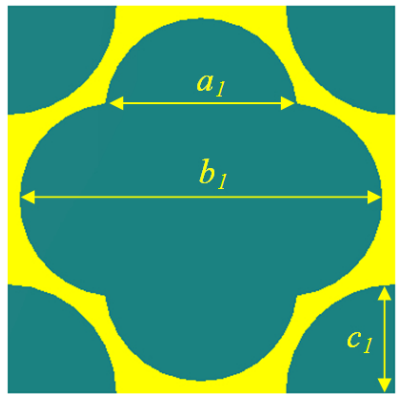

a

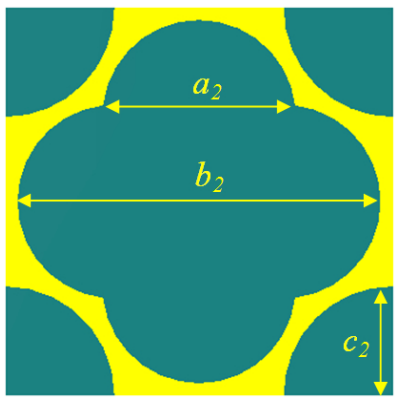

$\mathrm{C}$

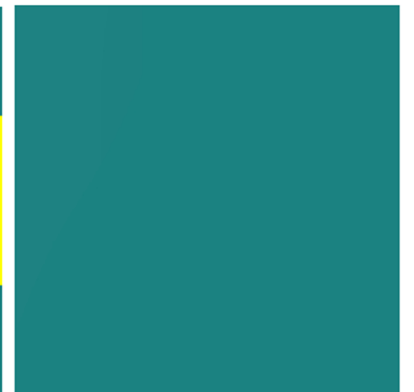

$\mathrm{b}$

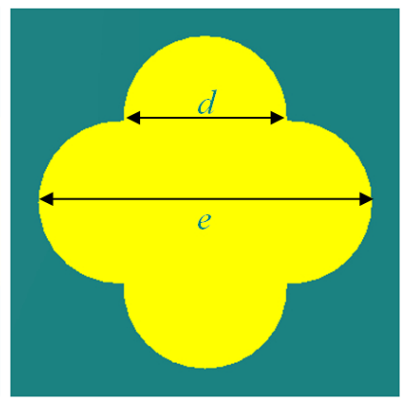

d
Fig. 2 - Configuration of the proposed PRS unit-cell, (a) bottom view of PRS layer 1, (b) top view of PRS layer 1, (c) bottom view of PRS layer 2, and (d) top view of PRS layer 2

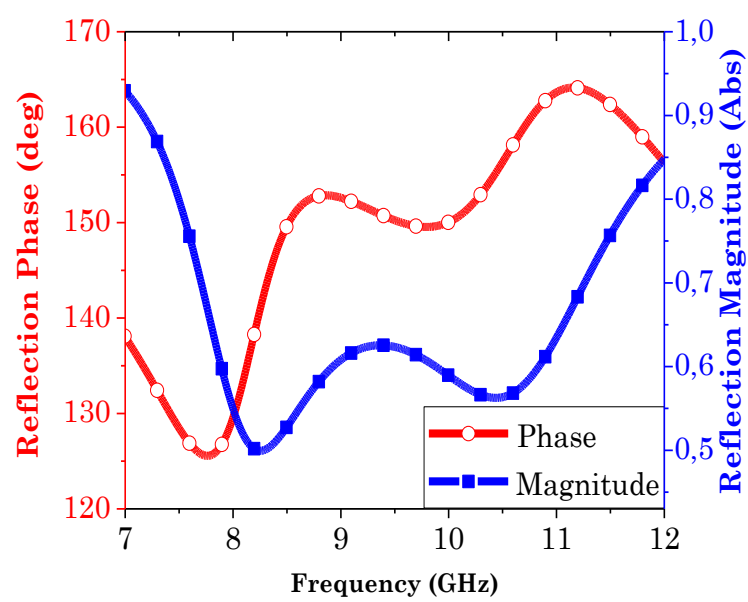

Fig. 3-Complex reflection coefficient for the proposed wideband PRS unit-cell

\section{PRS IMPLEMENTATION AND TEST}

In this section, the proposed PRS is implemented and tested to demonstrate its effectiveness for improving the gain of printed antennas. An array formed by $8 \times 9$ of the designed PRS unit-cell (Fig. 4) is implemented over a single-layer FA at an optimized elevation in order to enhance its gain. The geometry of the considered FA is presented in Fig. 5. The same substrate used to design the PRS with the same thickness is used to design the considered FA. The considered geometry of the FA is selected after an optimization process that permitted to enhance its operational bandwidth. The PRS and the considered FA were joined to each other at the required elevation by employing four nylon spacers (nylon $6 / 6, \varepsilon_{r}=2.94$ and radius $=1.46 \mathrm{~mm}$ ). The total configuration of the assembled antenna is shown in Fig. 6. All its optimized dimensions are specified as follows: $w=56 \mathrm{~mm}, g=18 \mathrm{~mm}, k=28 \mathrm{~mm}, l=4 \mathrm{~mm}$, $m=10 \mathrm{~mm}, n=18 \mathrm{~mm}, o=18 \mathrm{~mm}, p=3 \mathrm{~mm}, q=2 \mathrm{~mm}$, $r=64 \mathrm{~mm}, \quad s=72 \mathrm{~mm}, \quad u=1.4 \mathrm{~mm}, \quad v=10.38 \mathrm{~mm}$, $x=26.5 \mathrm{~mm}, y=1.93 \mathrm{~mm}, h_{1}=15.71 \mathrm{~mm}, h_{2}=13.46 \mathrm{~mm}$.

The two parameters gain and the reflection coefficient $\left(\mathrm{S}_{11}(\mathrm{~dB})\right)$ of the considered FA were simulated with and without PRS. As shown in Fig. 7, the reflection coefficient of the FA is slightly improved by about $160 \mathrm{MHz}$ after the implementation of the PRS. It extends from $9.08 \mathrm{GHz}$ to $11.28 \mathrm{GHz}$, which equates to $21.61 \%$. Despite the cuts removed from the ground plane of the FA, Fig. 8 illustrates that the gain response of the considered FA is significantly improved after the
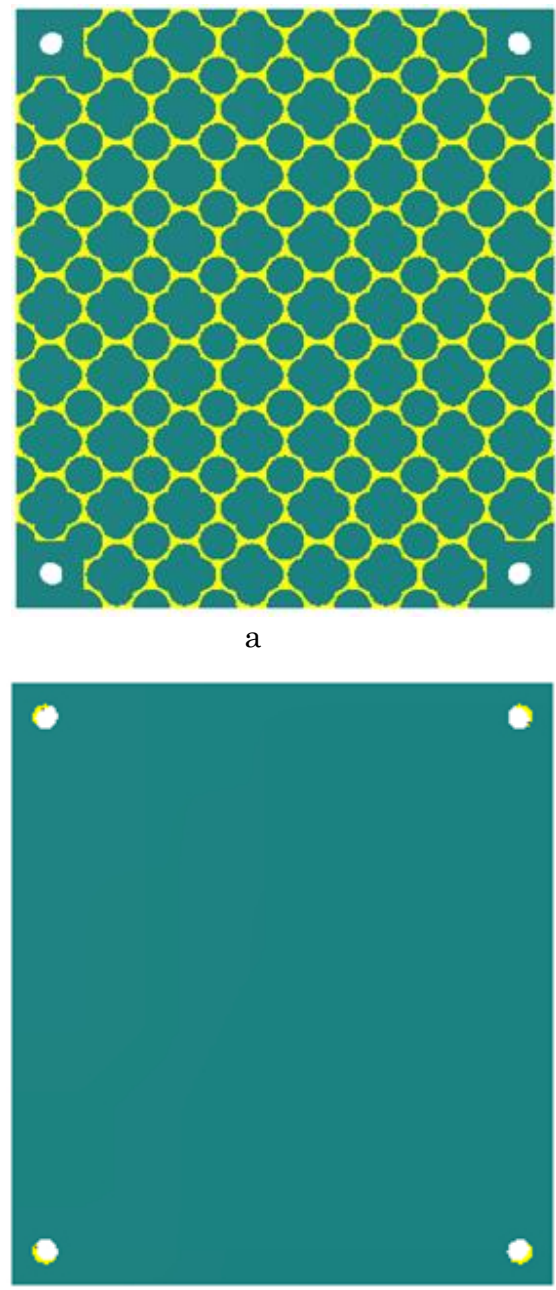

$\mathrm{b}$ 


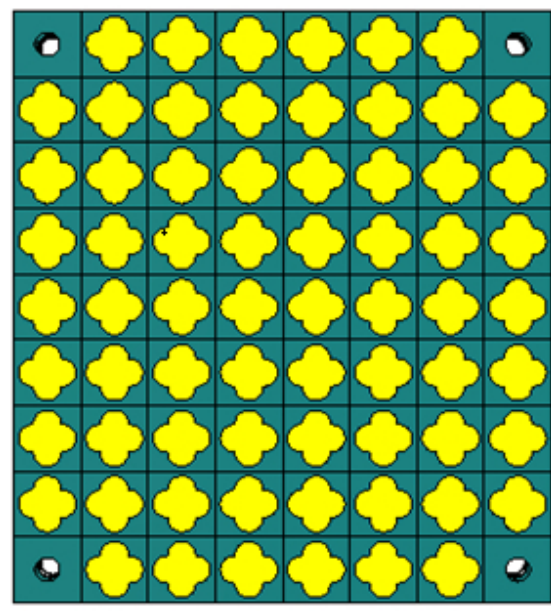

c

Fig. 4 - Configuration of the proposed PRS layers array: (a) bottom view of PRS layer 1 and PRS layer 2, (b) top view of PRS layer 1, and (c) top view of PRS layer 2
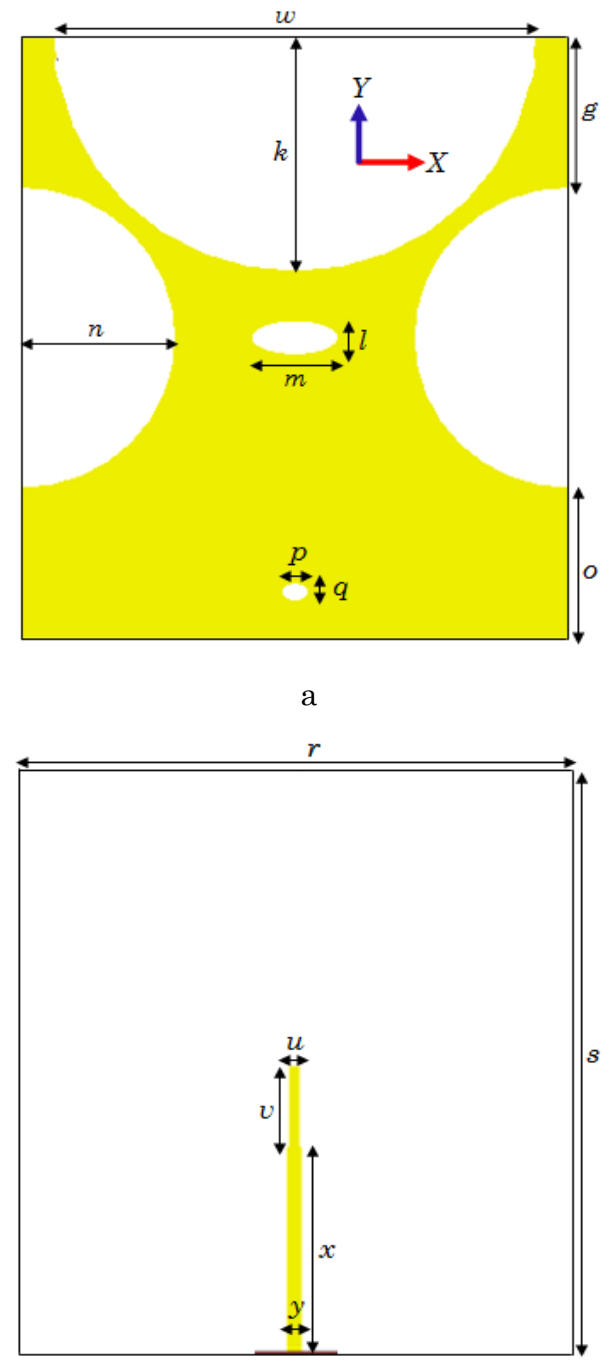

b

Fig. 5 - Geometry of the considered FA: (a) top view and (b) bottom view

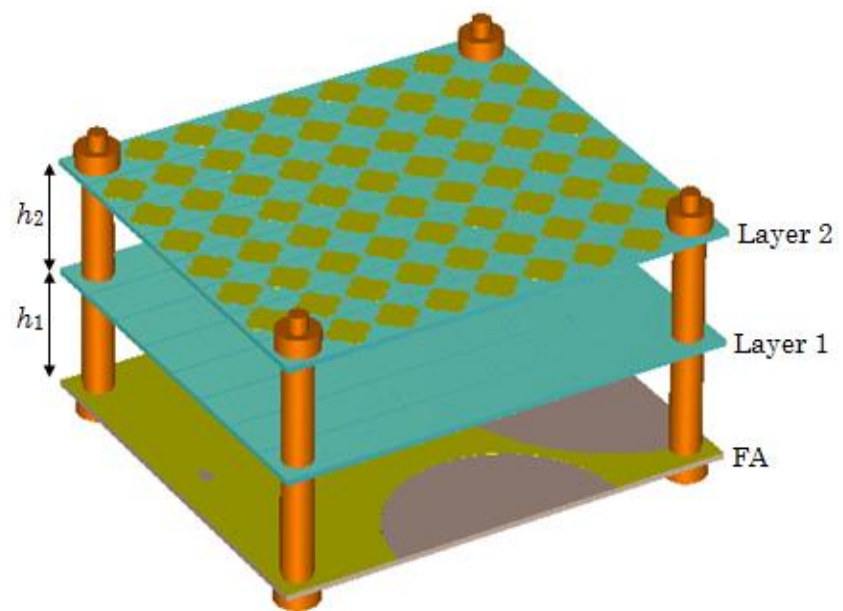

Fig. 6 - Perspective view of the proposed antenna with PRS layers

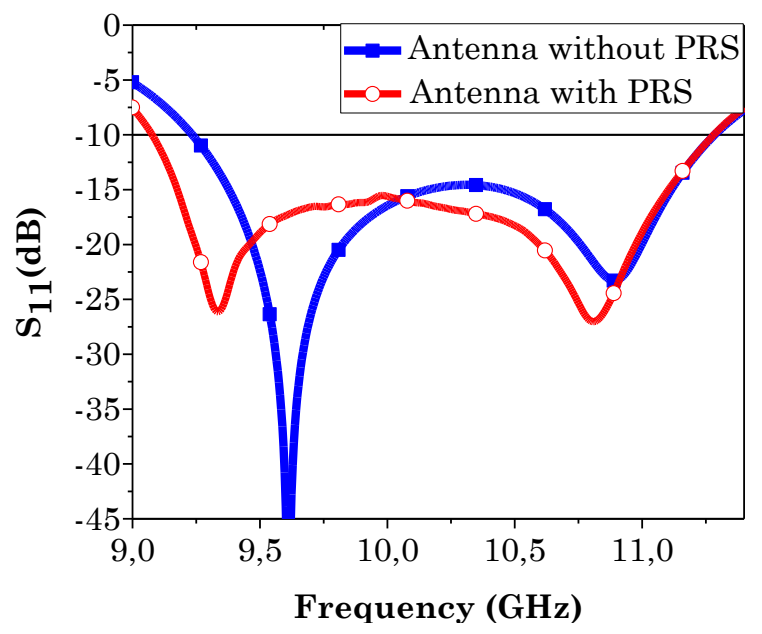

Fig. 7 - Influence of adding the designed PRS on the reflection coefficient of the considered FA

addition of the PRS; the gain increases by more than $2.51 \mathrm{dBi}$ along the working band. Because high gain can be achieved by high reflection of electromagnetic waves between the FA and the PRS, the use of the same considered FA without cuts along the borders of its ground plane will enhance more its gain but unfortunately the operational bandwidth will dramatically lessen. Fig. 9 depicts the simulated far-field $2 \mathrm{D}$ radiation patterns of the antenna with PRS at $10.25 \mathrm{GHz}$. It is evidently perceived that the main radiated beam is along the broadside direction with reasonably symmetrical radiation.

\section{CONCLUSIONS}

A broadband dual-layer PRS for printed antennas gain enhancement has been proposed in this paper. The proposed dual-layer PRS operates in a wideband ranging from $7.76 \mathrm{GHz}$ to $11.16 \mathrm{GHz}$. It is placed over a single-layer printed FA to demonstrate its effectiveness for antennas gain improvement along this band. The gain of the considered FA is considerably enhanced after the implementation of the PRS. Thus, the proposed PRS is useful for improving the gain of printed antennas operating in the X-band. 


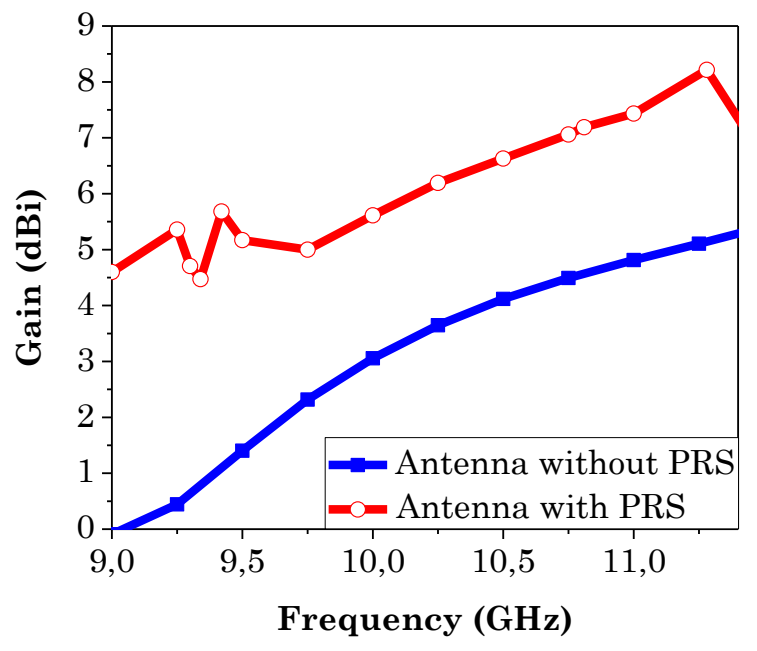

Fig. 8 - Influence of adding the designed PRS on the gain of the considered FA

\section{REFERENCES}

1. A. Chaabane, F. Djahli, H. Attia, T.A. Denideni, Frequenz. 71(5-6), 243 (2018).

2. S. Zaiter, N. Raveu, R. Oussaid, Int. J. RF Microw. C. E. 30(7), e22229 (2020).

3. A. Chaabane, F. Djahli, H. Attia, L.M. Abdelghani, T.A. Denideni, Microw. Opt. Techn. Let. 59(1), 98 (2017).

4. A. Chaabane, F. Djahli, H. Attia, T.A. Denideni, 17th International Symposium on Antenna Technology and Applied Electromagnetics (ANTEM-2016), 7550151 (Montreal: IEEE: 2016).

5. Y. Hu, Y. Wang, Z. Yan, H. Zhou, Microw. Opt Techn. Let. 62(2), 906 (2020).

6. S.B. Abdulkareem, S. Gopalakrishnan, Wirel. Commun. Mob. Com. 2020, 9578031 (2020).

7. M.A. Meriche, H. Attia, A. Messai, S.S.I. Mitu, T.A. Denideni, IEEE Antenn. Wirel. Pr. 18(9), 1771 (2019).

8. H. Attia, L.M. Abdelghani, T.A. Denideni, IEEE T. Antenn. Propag. 65(10), 5589 (2017)

9. L.M. Abdelghani, H. Attia, T.A. Denideni, IEEE Antenn. Wirel. Pr. 16, 473 (2017).

10. H. Attia, 12th European Conference on Antennas and Propagation (EuCAP-2018), 1236 (London: IEEE: 2018).

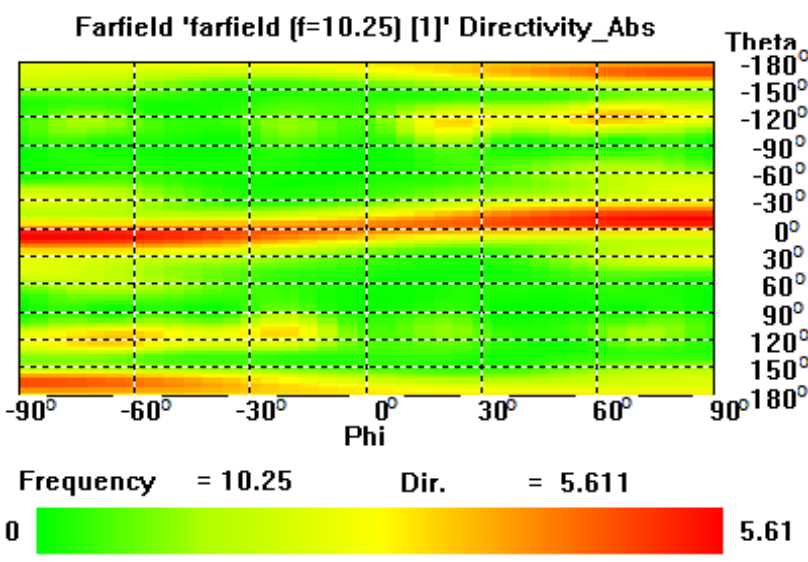

Fig. 9 - Far-field 2D radiation patterns at $10.25 \mathrm{GHz}$

\section{ACKNOWLEDGEMENTS}

This work was supported by the directorate general for scientific research and technological development (DG-RSDT) of Algeria.

11. N. Wang, Q. Liu, C. Wu, L. Talbi, Q. Zeng, J. Xu, IEEE T. Antenn. Propag. 62(5), 2463 (2014).

12. F. Qin, S. Gao, G. Wei, J. Xu, Microw. Opt. Techn. Let. 58(5), 1109 (2016)

13. A.P. Feresidis, J.C. Vardaxoglou, IEE P-Microw. Anten. P. 148(6), 345 (2001).

14. K. Konstantinidis, A.P. Feresidis, P.S. Hall, IEEE T. Antenn. Propag., 63(1), 423 (2015).

15. B.A. Zeb, K.P. Esselle, IET Microw. Antenna. P. 9(10), 1059 (2015).

16. B.A. Zeb, K.P. Esselle, IET Microw. Antenna. P. 10(2), 168 (2016).

17. L.Y. Ji, S. Fu, L.X. Zhang, J.Y. Li, Int. J. Microw. Wirel. Technol. 12(3), 233 (2020).

18. A. Lalbakhsh, M. U. Afzal, K. P. Esselle, S.L. Smith, IEEE T. Antenn. Propag. 67(3), 1975 (2019).

19. Z. Liu, S. Liu, J. Bornemann, X. Zhao, X. Kong, Z. Huang, B. Bian, D. Wang, IEEE Access. 8, 80183 (2020).

20. A. Goudarzi, M.M. Honari, R. Mirzavand, Electronics. 9(7), $1080(2020)$.

\title{
Нова широкосмугова частково відбиваюча поверхня для покращення коефіціента посилення антени
}

\author{
Abdelhalim Chaabane
}

Laboratoire des Télécommunications-LT, Département d'Electronique et Télécommunications, Faculté des Sciences et de la Technologie, Université 8 Mai 1945 Guelma, BP 401, Guelma 24000, Algeria

$\mathrm{y}$ роботі запропонована нова широкосмугова частково відбиваюча поверхня (PRS) для покращення коефіціента підсилення друкованих антен. Запропонована PRS побудована з двох шарів, розділених повітряним зазором. Вона складаеться з індуктивного патчу з отвором у формі зірки або квітки, протравленого на нижніх гранях його двох шарів, та емнісного патчу у формі зірки або квітки, розміщеного на верхній грані верхнього шару. Представлена PRS з функціонуванням у широкосмуговому діапазоні від 7,76 до 11,16 ГГц запропонована для покращення коефіцієнта підсилення друкованих антен, що працюють навколо ціеї смуги. Корисність запропонованої PRS досліджуеться шляхом розміщення масиву $8 \times 9$ над одношаровою друкованою антеною. Коефіціент підсилення розглянутої антени значно покращуеться після впровадження PRS. Отже, корисність розробленої PRS демонструеться для покращення коефіціента підсилення друкованих антен, що працюють в діапазоні частот X-зони.

Ключові слова: Частково відбиваюча поверхня (PRS), Широкосмуговий діапазон, Покращення коефіціента підсилення. 